\title{
RELATIONSHIP BETWEEN ACTIVE PHYSICAL EXERCISE AND SLEEP QUALITY WITH PHYSICAL FATIQUE IN ELDERLY ON HARAPAN BARU SAMARINDA PUBLIC HEALTH CARE
}

\author{
Ramdhany Ismahmudi $^{1}$, Alfi Ari Fakhrurizal ${ }^{1}$ \\ ${ }^{1}$ Program Studi Diploma III Keperawatan Universitas Muhammadiyah Kalimantan Timur. \\ *E-mail : ri984@umkt.ac.id
}

\begin{abstract}
Physical excercise is any form of activity by an individual, especially the elderly, in an effort to improve physical fitness and physical conditions, with the main objective being to increase strength, cardiorespiration endurance, speed, skills and flexibility. In the elderly, physical training aims to improve the quality of life, so they can get through their old days in a fit. The purpose of this study is to find out how the relationship between active physical activity and sleep quality with physical fatigue. This research is a descriptive qualitative study using a cross sectional. Sampling method is Total Sampling, with a total sample of 125 respondents. Data collection techniques using interview, observation, and questionnaires. Data processing and analysis using univariate analysis using frequency distribution tables for the description of the study, and multivariate analysis using chi-square analysis. The research activity was carried out for approximately 1 month starting from July 23-August 24, 2019 at the Harapan Baru Health Center. The results between physical activity with fatigue where 43 of 71 respondents (34\%) did not experience fatigue after doing physical activity, with a P-Value of $0.025<0.05$ and the OR value $=2,298$ shows that the elderly who are active in physical activity will not experience physical fatigue. For the sleep needs variable of 39 people $(31 \%)$ of respondents with sleep deprivation problems do not experience fatigue, with a P-Value of $0.442>$ 0.05 . With OR value $=0.755$ where elderly people who have adequate sleep will not experience physical fatigue.
\end{abstract}

Keywords: Latihan Fisik, KualitasTidur, Kelelahan Fisik,Kondisi Fisik, Lansia.

\section{INTRODUCTION}

Elderly experienced setbacks in various aspects, especially physical abilities that caused the occurrence include physical abilities that cause disruption in meeting the needs of life so as to increase dependence on others.Physical activity has a big impact on health. Some effects are well established; as a major component of energy expenditure, physical activity has a major influence on energy balance and body composition. It is also recognized that physical activity is a major, unmodifiable risk factor that has a protective effect against heart disease, stroke, type 2 diabetes, colon, and breast cancer, and is also associated with other important health outcomes such as mental health, injury, and falls ${ }^{1}$. Some physical activity that is suitable and suitable for elderly people to do such as aerobic exercise, muscle strengthening, and flexibility exercises. When doing physical exercise several things that affect the physical activity of the elderly include body composition, flexibility, muscle strength, and endurance of the pulmonary heart ${ }^{2}$.Some studies also explain that the prevalence of sleep disorders in the elderly is quite high at around $67 \%{ }^{3}$. The elderly often report having difficulty falling asleep to be able to fall asleep while in bed. Sleep quality is a condition where sleep experienced by an individual produces freshness and fitness when waking up from sleep. 
Sleep quality that includes quantitative aspects of sleep, such as duration, sleep retention, and subjective aspects, such as deep sleep and rest. Changes in sleep patterns in the elderly are caused by changes in the nervous system that are physiologically where this results in the function of neurotransmitters in the nervous system decreases ${ }^{4}$. In research on sleep disorders in which the researchers found that sleep disturbance and lack of activity negatively influence each other ${ }^{5}$.

The phenomenon found by researchers in the Harapan Baru Health Center Elderly Service Room is a complaint of illness that is always associated with physical fatigue of elderly patients. Patients complain of headaches associated with lack of sleep, unable to sleep, sleep soundly because this condition causes him to experience physical fatigue and even unable to do physical activity that is too heavy. Information obtained from interviews with Puskesmas staff holding the elderly health program is a problem that is always complained of by the elderly when they come for treatment or visits both at the Puskesmas and at the posyandu where the disorders complained of when they arrive are always related to problems related to physical fatigue. Some of the elderly also said that they also participated in active physical activities at the Posyandu, and they said that with these activities they never felt any physical fatigue. Improved physical quality in the elderly will also affect general health, such as blood pressure and pulse to stay within normal limits when the elderly are at rest. Based on this background, researchers are interested in examining the purpose of seeing the extent of the relationship between active physical activity and sleep quality in an elderly person with physical fatigue in the elderly in the work area of the Harapan Baru Health Center in Samarinda with the aim of improving the living standards of the elderly.

\section{MATERIAL AND METHOD}

This study was conducted for approximately 1 month starting from 23 July - 24 August 2019 at the HarapanBaru Health Center in Samarinda, with the sampling method being a total sampling with a total sample of 125 elderly people who were active in the Posyandu Elderly. All respondents who participated in the data collection activity actively answered and responded to the questions asked by the Research team. Data obtained in research activities were analyzed computerized using statistical software. The data in this study were analyzed with 2 models, namely univariate and bivariate analysis. Univariate analysis is directed to describe the frequency distribution of the variables analyzed using descriptive statistical methods, after which the data will be presented in the form of frequency distribution tables to find out the proportions of each variable. The bivariate analysis of the researchers used the chi-square test with the significance of $p<0.05$ to find out the extent of the relationship between the dependent and independent variables of this study or in other words to see the extent of the relationship between physical activity undertaken by the elderly and sleep quality with physical fatigue. 


\section{RESULTS AND DISCUSSION}

After conducting research activities, a univariate analysis was performed for each variable and the results can be seen in the table below

\begin{tabular}{clcc}
\hline NO & \multicolumn{1}{c}{ VARIABEL PENELITIAN } & n & \% \\
\hline & Aktivitas Fisik & 71 & 57 \\
1. & Tinggi & 54 & 43 \\
& Rendah & & \\
\hline \multirow{2}{*}{ Kebutuhan Tidur } & Baik & 68 & 54 \\
& Kurang & 57 & 46 \\
\hline & Kelelahan Fisik & & \\
3. & Tidak Lelah & 72 & 58 \\
& Lelah & 53 & 42 \\
\hline
\end{tabular}

In table 1 above shows that of 125 respondents for the variable physical activity shows that the majority of respondents are in the high category with the number of respondents as many as 71 people (57\%), for the sleep needs of 125 respondents indicate the majority of good sleep needs with the number of respondents as much 68 people (54\%), and for the variable physical fatigue the majority of respondents are in the category of Tired with the number of respondents as many as 72 people (58\%).For bivariate analysis for each variable can be seen in Table 2 below:

\begin{tabular}{|c|c|c|c|c|c|}
\hline \multirow{2}{*}{ Aktivitas Fisik } & \multicolumn{2}{|c|}{ Kelelahan } & \multirow{2}{*}{ Total } & \multirow{2}{*}{$\begin{array}{c}P \\
\text { Value }\end{array}$} & \multirow{2}{*}{$\begin{array}{c}\text { OR } \\
\text { CI }(95 \%)\end{array}$} \\
\hline & Lelah & Tidak Lelah & & & \\
\hline \multirow{2}{*}{ Baik } & 28 & 43 & 71 & \multirow{4}{*}{0,025} & \multirow{4}{*}{$2,298(1,104-4,785)$} \\
\hline & $22 \%$ & $34 \%$ & 57 & & \\
\hline \multirow{2}{*}{ Kurang } & 25 & 29 & 54 & & \\
\hline & 20 & 23 & 43 & & \\
\hline \multicolumn{6}{|l|}{ Kebutuhan Tidur } \\
\hline \multirow{2}{*}{ Cukup } & 35 & 33 & 68 & \multirow{4}{*}{0,442} & \multirow{4}{*}{$0,755(0,369-1,546)$} \\
\hline & 28 & 26 & 54 & & \\
\hline \multirow{2}{*}{ Kurang } & 18 & 39 & 57 & & \\
\hline & 14 & 31 & 46 & & \\
\hline
\end{tabular}

In table 2 above it can be seen that between physical activity and fatigue where 43 out of 71 respondents (34\%) did not experience fatigue after doing physical activity, the statistical test found that the P-Value $0.025<0.05$, so it can be stated that there is a relationship Significant between physical activity with fatigue experienced by the elderly, for the value of OR = 2,298 shows that although the elderly who are active in physical activity will not experience fatigue.

Physical activity is human behavior characterized by body movements from skeletal muscle that produce energy expenditure ${ }^{6}$. An experimental study of how active physical exercise can modulate brain-derived peripheral neurotropic factors (Brain-Derived Neurotrophic Factor / BDNF). In this study, in which the research subjects were grouped into 5 control groups and 
5 treatment groups, the results showed that 5 groups had very significant differences between groups doing active physical activity in the form of aerobic exercise with changes in peripheral neurotropic factors, in other words, could the conclusion is that good physical activity in the elderly will affect changes in brain quality and will certainly reduce the occurrence of problems related to brain disorders such as dementia ${ }^{7}$.

This is also appropriate with other studies that examine physical exercise in the elderly have an impact on increasing changes in the brain structure of the elderly, wherein this study observation was made on the elderly who were actively exercising continuously without any disturbance indicating a change in the structure of the brain where it changed in the structure of the left hippocampus and in the bilateral brain nucleus ${ }^{8}$. Certain sports can be useful to overcome sleep disorders, one of which is insomnia. One of the sports that can improve the fulfillment of sleep needs is regular elderly exercise ${ }^{9}$. Based on other research shows there is a positive relationship between regular gymnastics elderly with the fulfillment of elderly sleep needs ${ }^{10}$. The frequency of exercises that are useful for maintaining and improving physical fitness is done at least once a week and as much as five times a week with a duration of 15 minutes ${ }^{11}$. It can be concluded that good physical activity in the elderly will affect their physical fitness so that to do other activities the elderly can continue to do it.

For the sleep needs variable of 39 people (31\%) of respondents with the problem of lack of sleep do not experience fatigue, the statistical test obtained a P-Value of $0.442>0.05$, so it can be stated that there is no significant relationship between sleep needs and fatigue experienced by an elderly person. The $\mathrm{OR}=0.755$ shows that even the elderly who have adequate sleep will not affect the occurrence of physical fatigue. According to research that examines sleep health, lifestyle, and mental health in the elderly in Japan where the results of the study show short naps (30 minutes between 1300 and 1500 hours of sleep) and moderate sports activities such as walking are very important in efforts to maintain and improve sleep quality in the elderly. In this study, the variables studied were the effects of short naps and offset moderate physical activity carried out for 4 consecutive weeks showing a significant change in the quality of health of the elderly themselves, in addition to physical health as well as mental health ${ }^{12}$. These results indicate that this intervention is very effective in improving sleep quality and daily activities in the elderly. From this, it can be concluded that the need for sleep can affect physical fatigue that is experienced by the elderly so that the more adequate sleep a person, the better the level of physical and psychological fitness.

\section{CONCLUSION}

From the conclusions obtained from the variable physical activity and sleep needs can affect the physical undertaken by the elderly. The more physical activity and the elderly, the better the level of physical and psychological fitness.

\section{ACKNOWLEDGEMENT}

Expression Thank you for the financial assistance provided by the Indonesian Ministry of Education's Directorate of Higher Education for the financial assistance that has been provided through the Program Penelitian Dosen Pemula (PDP) in 2019 so that this research activity can be carried out as expected. Do not forget also to all those who have provided 
assistance to support data collection activities in research, especially the Samarinda Harapan Community Health Center.

\section{REFERENCES}

1. Miles, 2007. Physical Activity and Health. Journal compilation British Nutrition Foundation Nutrition Bulletin,32, pp. 314-363.

2. Ambardini RL, Aktivitas Fisik pada Lanjut Usia. Yogyakarta, UNY (2009)

3. Amir, N, Gangguan Tidur pada Lanjut Usia. Diagnosis dan Penatalaksanaan, dalam Cermin Dunia Kedokteran, Grup PT. Kalbe Farma, Jakarta, hlm.196-206 (2007).

4. Khasanah dan Hidayati, Kualitas Tidur Lansia Balai Rehabilitasi Sosial "MANDIRI" Semarang. Jurnal Nursing Studies, 1(1) : 189-196 (2012)

5. Hemalova garmas, F. U. Sleep disorders and activities in long term care facilities avicious cycle? .Jurnal Kesehatan Psycology (2010)

6. Caspersen CJ, Powell KE, Christenson GM. Physical activity, exercise, and physical fitness: definitions and distinctions for health-related research. Public Health, pp. 100:126-31. (1985)

7. Coelho, F. G. de M., Gobbi, S., Andreatto, C. A. A., Corazza, D. I., Pedroso, R.V., \& Santos-Galduróz, R. F. Physical exercise modulates peripheral levels of brain-derived neurotrophic factor (BDNF): A systematic review of experimental studies in the elderly. Archives of Gerontology and Geriatrics. https://doi.org/10.1016/j.archger.2012.06.003. (2013).

8. Boyke, J.,Driemeyer, J. Et.al. Training-Induced Brain Structure Changes in the Elderly. The Journal of Neuroscience, pp. 7031-7035 (2008).

9. Yanuarita, A.F, Memaksimalkan Otak Melalui Senam Otak (Brain Gym), CV. Solusi Distribusi, Yogyakarta, (2012).

10. Mahardika, J., Haryanto, J., \&Bakar, A. Hubungan Keteraturan Mengikuti Senam Lansia Dan Kebutuhan Tidur Lansia Di UPT Surabaya: Keperawatan Universitas Airlangga, (2011)

11. Maryam, S et all. Mengenal Usia Lanjut dan Perawatannya, Salemba Medika, Jakarta (2008) 